\title{
Community-Based Watershed Restoration in Nepal: Learning from EBA South Project
}

\author{
TejKumar Shrestha ${ }^{1,2 *}$, Sunita Shrestha ${ }^{1,3}$, Sarita Lawaju ${ }^{1}$, Anish Parajuli ${ }^{1}$ \\ ${ }^{1}$ Lumbini Environmental Services Pvt. Ltd., Kathmandu, Nepal \\ ${ }^{2}$ Khwopa College, Bhaktapur, Nepal \\ ${ }^{3}$ Nepal Academy of Medical Sciences, Kathmandu, Nepal
}

\begin{abstract}
*Corresponding Authors: Tej Kumar Shrestha, Lumbini Environmental Services Pvt. Ltd., Kathmandu, Nepal.
\end{abstract}

\begin{abstract}
Climate change is advancing more rapidly in the high Himalayas than in many other parts of the world, affecting both people and natural systems. Adaptation is now recognized as an essential part of the global response to climate change, so ecosystem-based approach has evolved to use biodiversity and ecosystem services as a part of an overall adaptation strategy to help vulnerable people to adapt adverse impacts of climate change. Ecosystem-based Adaptation through South-South Cooperation (EbA South) is a full-sized Global Environment Facility $(G E F)$ project, which aims to reduce vulnerabilities of local communities from climate change effects through increasing institutional capacity, mobilizing knowledge and transferring appropriate best-practice adaptation technologies and application of ecosystem-based approaches on-the-ground interventions. The onthe-ground interventions have been conducted in different sites of Lamjung, Tanahuh and Gorkha districts in Nepal, that are highly vulnerable to climate change effects including floods, landslides, droughts and glacial lake floods. EbA South project adopted basic approach of EbA to increase social and ecosystem resilience to climate change through building capacity in Nursery establishment, seedling production and plantation techniques, distribution and plantation of climate resilient seedlings for reforestation and agro-forestry, bamboo suckers and Salix seedlings on degraded river banks and seedlings in fruits orchards at project sites. More than 3,000 households were benefited through involvement in project activities. Restoration of degraded forest and land increased resilience of climate vulnerable people to cope with disaster such as landslide and soil erosion. Plantation helped community to combat soil erosion, increase ground fertility, provide fodder and improve income source through selling of fruits, broom, parts of plants for medicine. The beneficiaries were positive and enthusiastic towards EbA South project activities.
\end{abstract}

Keywords: Climate change, Ecosystem based Adaptation, Reforestation, Nursery, Seedlings

\section{INTRODUCTION}

Nepal's climate is extremely complex and varied partly due to its topography, the extraordinary variation in elevation from the plains to the Himalayan high mountains, and the influence of the Himalayan mountain range and the South Asian monsoon (MOE, 2010). Nepal is considered as one of the top ten countries most likely to be impacted by global climate change (WFP, 2009) but is one of the least contributors to the emissions of Greenhouse Gases (GHGs), i.e. $0.027 \%$ of global share (INDC, 2016) but it is considered a global warming hotspot because of the direct impact on local resources (MOE, 2010). The National Adaptation Programme of Action (NAPA) published in 2010 by then Ministry of Environment, Government of Nepal reported a trend of observed warming for Nepal of approximately $0.4^{\circ} \mathrm{C}$ to $0.6^{\circ} \mathrm{C}$ per decade. Climate change impacts are becoming increasingly visible and affect economic and productive sectors in Nepal. Climate related impacts have negatively affected Nepal in several ways, including an increase in Glacial Lake Outburst Flood disasters, the destruction of hydropower and irrigation infrastructure, biodiversity loss and limited access to domestic water usage. According to predictions made by experts, Nepal will face many challenges, such as decline in agricultural productivity, loss of agro biodiversity and worsening food insecurity over the coming decades due to climate related variability (IPCC , 2007). 
Despite adaptation to climate variability, fast-changing climate is impacting the ecosystem goods and services on which people rely, so it is critical to develop adaptation capabilities to be able to deal with these challenges. Ecosystem-based Adaptation (EbA), are cost-effective solutions that can help people adapt to the impacts of climate change involving the conservation, sustainable management and restoration of ecosystems (IUCN, 2017). EbA is broadly defined as "a range of local and landscape scale strategies for managing ecosystems to increase resilience and maintain essential ecosystem services and reduce the vulnerability of people, their livelihoods and nature in face of climate change" (UNFCCC, 2008).

\section{EBA SOUTH}

Ecosystem-based Adaptation through South-South Cooperation (EbA South) is a full-sized Global Environment Facility (GEF) project, funded through Special Climate Change Fund (SCCF), implemented by United Nations Environment (UN Environment) and executed by the National Development and Reform Commission of China (NDRC), through the Institute of Geographic Sciences and Natural Resources Research, Chinese Academy of Sciences (IGSNRR, CAS). The project EbA South entitled "Enhancing Capacity, Knowledge and Technology Support to Build Climate Resilience of Vulnerable Developing Countries" aims reducing vulnerabilities of local communities from climate change effects through application of ecosystem-based approaches. Such approaches include on-the-ground interventions, increasing institutional capacity, mobilizing knowledge and transferring appropriate best-practice adaptation technologies. This project has been piloted in three countries i.e. Mauritania, Nepal and Seychelles since 2013, representing three different vulnerable ecosystems i.e. Dry land, mountain and coastal respectively. The Ministry of Forests and Environment (MoFE) of Nepal has been working as one of the executing partners of the project responsible for the pilot EbA interventions in selected project sites in Nepal. In Nepal, EbA (South) Project started in 2013 in Lamjung district. Intensive activities were implemented in Chiti and Jita (former VDCs). Later best learning of these sites was scaled out in few regions of Tanahuh and Gorkha districts. The concrete, on-the-ground interventions have been conducted in different sites of Lamjung, Tanahuh and Gorkha districts in Nepal, that are highly vulnerable to climate change effects including floods, landslides, droughts and glacial lake floods.

Adaptation is necessary to deal with adverse stresses and hazards (Smit, Burton, Klein , \& Street , 1999) and build resilience of communities so that they can sustain their livelihoods even in extreme shocks and stresses (Regmi \& Bhandari, 2013). This paper summarizes the adaptation approaches for restoration of degraded land through EbA South project based on three components i.e. capacity building, technical support and knowledge management under EbA South project.

\section{WORKING AREAS OF PROJECT}

EbA South interventions were implemented in three districts namely Lamjung, Gorkha and Tanahun.

Lamjung: Project activities were implemented in Chiti (site 1), Jita (site 2) and other parts of Lamjung. The landscape of site 1 is characterized by a Marshyangdi river flowing in a northwesterly direction on its southern border at an altitude of about 670-1260 meters above mean sea level (amsl). When viewed from its southern boundary, the site is covered by three distinct classes of land types i.e. grassland, agricultural land and community forest.

The landscape of site 2 is characterized by the long south-facing slopes across deep valleys at an altitude of 800-1350 meters amsl. The predominant land cover is terraced agriculture land on the slope, with strips of community forests extending to the foot of mountains along the valleys. However, the terraces on the upside of the slope were poorly maintained and are now used as pasture for raising livestock. Meanwhile, the forests are only slightly degraded, with relatively small bare areas inside that are generally inaccessible.

EbA South project distributed and planted tree seedlings, bamboo rhizomes and large Cardamom to the residents and farmers beyond the two specific sites (site $1 \&$ site 2).

Gorkha: Tunebote bagar, Harmi VDC (Site 1) and Bhandaarthok, Palungtaar Municipality-3 (Site 2) were selected as project site. Site 1 is in the riverbank and edge of the Gorkha district alongside the Chepe river at an altitude of 550-560 meters amsl, which has been utilized for cattle grazing. Site 2 is scattered in abandoned farmland of seven farmers of Bhandaarthok, Palungtaar Municipality ward no 3 at an altitude of 600-650 meters amsl. 
Tanahun: Different VDCs of Tanahun were selected as intervention site of the project. Tanahun district is dominated by forest area and agricultural land contributing $50.52 \%$ forest and $41.36 \%$ agricultural land respectively.

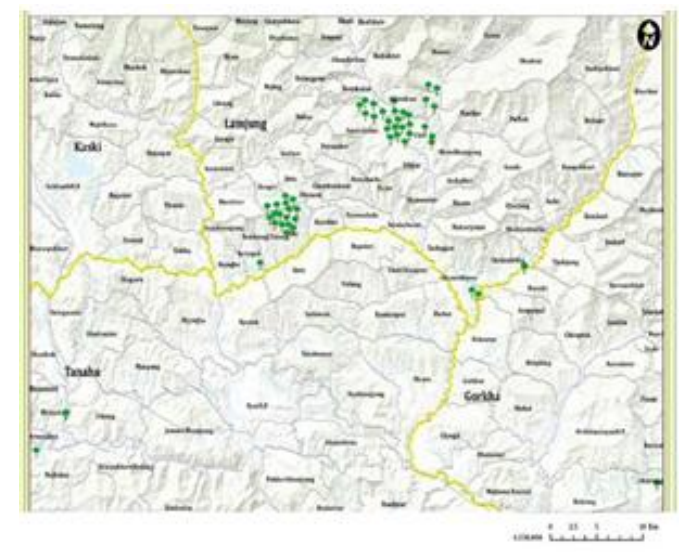

Figure1. Project intervention sites

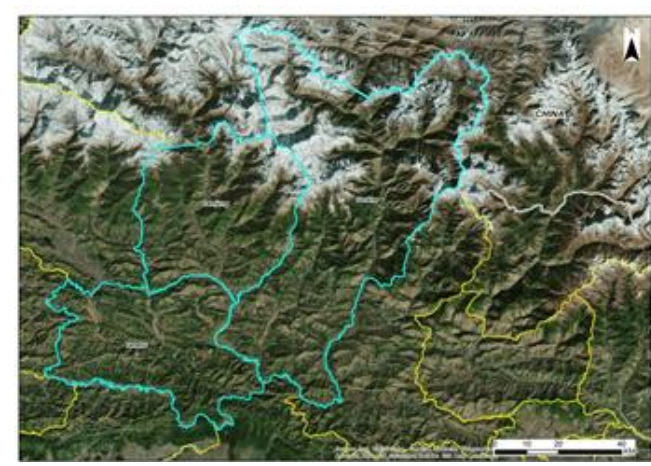

Figure2. Location map showing working areas

\section{Project Interventions}

Site Specific interventions are detailed as per the below indicators and targets of the project.

Target 1: At least 1 long term monitoring site established in Nepal.

Indicators: Number of long-term monitoring points established at intervention sites in Nepal for measuring the effects of EbA on relevant ecosystem services.

Target 2: At the end of the project, at least 2 of the following documents on EbA developed (at least first draft) in Nepal:

- $\quad$ post-graduate theses;

- research reports co-authored by government staff;

- peer reviewed research articles prepared for national scientific journals;

- popular articles;

- school project reports.

Indicators: Number of research reports, theses and publications developed by students and government staff conducting long-term research on the effects of EbA.

Target 3: Minimum of 200 people reached.

Indicators: Public awareness activities carried out and population reached.

\section{Target 4:}

Target 4.1: 500,000 seedlings planted in Chiti (Site 1), Jita (Site 2) and/or surrounding areas. 370,000 climate-resilient seedlings planted for reforestation, enrichment and/or household agro forestry in sites 1,2 , surrounding areas and neighboring districts. 30,000 bamboo suckers and/or banana and Salix 
seedlings planted on degraded river banks in site 1. 100,000 seedlings/rhizomes/suckers planted in fruit orchards, large cardamom plantations and/or broom grass plantations in site 1 and/or 2 .

Target 4.2: Crop production diversified through ginger and vegetable planting in 150 households in site 1.

Target 4.3 (complementary to Target 4.2): Livelihoods improvement of communities through:

beekeeping with new-style beehives for honey harvesting. Water source conservation by construction and maintenance of water source and ponds; improved cooking stoves and associated trainings delivered to household in Lamjung.

Indicators: Number of EbA interventions implemented.

Target 5: 40\% survivorship of plantations

Indicators: Survivorship of plantations at project demonstration sites.

Target 6: At least 4 new livelihood options being practiced.

Indicators: Number of alternative livelihoods from ecosystem goods and services developed through the project and providing benefits to local communities.

\section{EbA and Climate Change}

Nepal is a mountainous Least Development Country (LDC) in South Asia. Climate change is advancing more rapidly in the high Himalayas than in many other parts of the world, affecting both people and natural systems (IPCC, 2007) and in Nepal this is likely to be exacerbated by rapidly rising temperatures. Adaptation is now recognized as an essential part of the global response to climate change so, development actors are increasingly promoting a community based approach that recognizes the unique risks faced by poor and marginalized people, and ecosystem based approach that has evolved to use biodiversity and ecosystem services as a part of an overall adaptation strategy to help vulnerable people to adapt adverse impacts of climate change (WWF, 2019). EbA South project adopted basic approach of EbA to increase social and ecosystem resilience to climate change through plantation of climate resilient seedlings for reforestation and agro-forestry, bamboo suckers and Salix seedlings on degraded river banks and seedlings in fruits orchards at project sites. Further, crop diversification such as ginger, cardamom and tunnel farming and different livelihood options such as bee keeping, Improved cooking stoves were promoted. Seventy-five groups or community organizations and local instructions and 936 households were directly benefited from implementation of the project. More than 3,000 households were benefited through involvement in project activities. (Bogati \& Bhuju, 2019).

\section{Restoration of Degraded Land}

EbA South project were implemented to strengthen the capacity at regional, national and local levels, sharing the available information to aware vulnerable communities and supporting to transfer the adaptation technologies at ground level in integrated way. The EbA South project has three main components i.e. capacity building, technical support and knowledge management.

\section{Capacity Building}

Due to rapid change in climate, adaptation has become complicated in practice as its impact is interlinked with a range of social, economic and political processes (Ayers , 2011). Therefore, vulnerable communities need to respond to climate change without delay, to enable them and their ecosystem to keep up with the ongoing and potential changes in climate system (Regmi \& Bhandari, 2013). One of the targets of the EbA South project was to aware and build capacity of at least 200 people. Public awareness and training activities were organized both on the central level and on the ground, through knowledge sharing, capacity building and awareness enhancement in intervention sites benefiting 330 participants (77\% male and 23\% female) (Bogati \& Bhuju, 2019).

Table1. Number of beneficiaries from training

\begin{tabular}{|l|c|c|c|}
\hline Training & Male & Female & Total \\
\hline National and local Training of Trainer & 41 & 11 & 52 \\
\hline Modeling cost benefit analysis and ecosystem services & 24 & 7 & 31 \\
\hline
\end{tabular}




\begin{tabular}{|l|c|c|c|}
\hline Alive planning tool & 27 & 5 & 32 \\
\hline GESI & 20 & 5 & 25 \\
\hline Mainstreaming of EbA in LAPA & 142 & 48 & 190 \\
\hline Total & $\mathbf{2 5 4}$ & $\mathbf{7 6}$ & $\mathbf{3 3 0}$ \\
\hline
\end{tabular}

Source: (Bogati \& Bhuju, 2019)

DFO Lamjung organized school campaign for enhancing awareness about various environmental issues such as climate change, biodiversity, REDD, forest fire and EbA intervention among teachers and students. 543 participants (47\% female and 53\% male) benefited from this campaign (Bogati \& Bhuju, 2019). Various training activities were organized in district level to build capacity on Nursey establishment, seedling production and plantation techniques for climate resilient seedlings. Through this project, nursery establishment, seedling production and plantation techniques protocol was developed to provide insight of how Nursery is set to produce seedling and how these seedlings are planted in field.

\section{NurSery Establishment \& SeEdLing Production TeChniQueS}

\subsection{Nurseries}

Sound nursery practice is the foundation of successful plantation program (Munjuga, et al., 2013) The project provided support for establishment of two nurseries in Chiti and Jita and seedling production in Archalbot. To ensure proper management of nursery, the project provided training on selection for nursery, setting of nurseries, nursery layout and construction, etc. for nursery staffs.

\subsection{Considerations in Nursery Establishment}

For a good plantation and proper raising of seedlings, four considerations i.e. site, size, duration of use and facilities should be considered during the establishment of a forest nursery (Khanna,1991) ;

\subsection{Setting of Nurseries}

Nursery site must be selected based on objectives, species of plants to be raised, and their distribution considering water supply, soil, access, aspect, slope, altitude, labour availability etc.

\subsection{Nursery Layout and Construction}

In designing the layout of nursery, provision will have to be made for seedlings in polypots, and paths. If stumps or bare-root transplants are to be raised, space for them will need to be allocated.

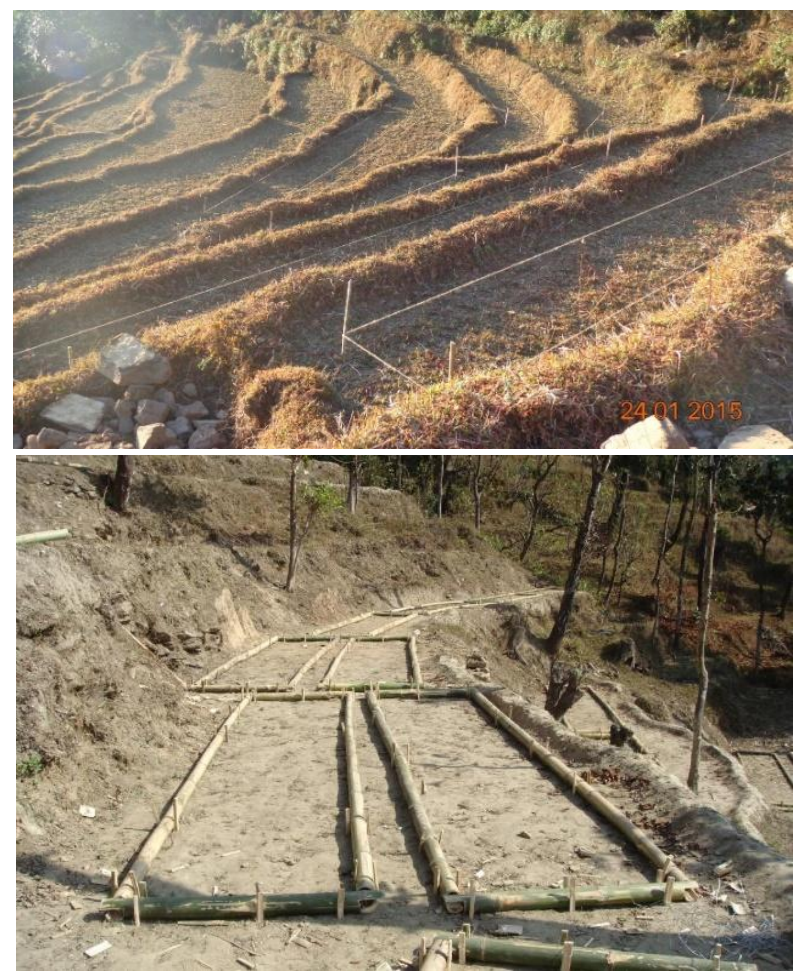




\subsection{Nursery Beds}

Generally, Nursey bed must have width of 1-1.2 m and length of 5-10. The seed to be sown in a bed depends on the weight of the seed, its germination percent and the desired number of seedlings.

\section{Type of Planting Stock}

\subsection{Container-Raised Plants}

The standard containers for raising plants are of two sizes 4-inch X 7 inch $(10 \mathrm{~cm} \mathrm{x} 18 \mathrm{~cm})$ and 3 inch $X 7$ inch $(7.5 \mathrm{~cm} \times 18 \mathrm{~cm})$ lay-flat. They are made of transparent 200 -gauge polythene with two holes on the side to drain out water and closed at the bottom.

\subsection{Bare-Root Plants}

Among the few species raised satisfactorily as bare-root plants in Nepal are Alnus nepalensis and Cryptomeria japonica.

\subsection{Large Ball-Rooted Seedlings}

These are plants $75-150 \mathrm{~cm}$ tall, grown in the nursery for 15 months or longer, and lifted with a ball of soil around their roots $10-15 \mathrm{~cm}$ in diameter, which is usually wrapped in grass, sacking, etc. to keep it moist during transport. Large ball rooted seedlings in general, are used for road side plantations or other ornamental plantations.

\subsection{Stumps (Root Shoot Cuttings)}

The root diameter of stump must be more than $7 \mathrm{~mm}$. The length should be around $15-20 \mathrm{~cm}$. The stumps of two species Dalbergia sissoo and Tectona grandis used usually require 14-16 months in the nursery to reach the required stump size. The following species can be propagated by root-shoot cutting or stump planting: Albizia procera (Seto siris), Bauhinia variegate (Koiralo), Cedrela toona (Tooni), Dalbergia sissoo (Sissoo), Ficus nemoralis (Dhudhilo), Ficus semicordata (Khanyu), Melia azedarach (Bakaino), Morus alba (Kimbu), Sapindus mukorossi (Ritha), Schima wallichii (Chilaune), Tectona grandis (Teak), Terminalia alata (Saj), Populus ciliata (Bangekath), Populus delttoides (Laharepipal).

\subsection{Cuttings}

Seeds of some species such as Taxus, Picea, Larix, and Cupressus germinate slowly due to embryo dormancy but those species could be raised by cuttings. Cuttings should be $15-25 \mathrm{~cm}$ long and 0.8 $2.5 \mathrm{~cm}$ in diameter, with at least two, and preferably four, nodes. Long thin side branches with elongated internodes, should not be used. The cuttings are inserted vertically into the pots or beds so that only one but remains above the soil level. In beds they should be $30 \mathrm{~cm}$ apart.

\subsection{Potting Mixtures}

To produce better quality nursery stock, the potting mixture should be sandy, with 40-70 \% sand content. The ideal potting mixture should be light, homogeneous, fertile, slightly acid ( $\mathrm{pH}$ 4.5- 6.0), well drained, but retaining enough water, sufficiently cohesive so that the root ball remains intact after the polypot is removed.

\subsection{Soil Sterilization}

It is strongly desirable that the sand, or soil and sand mixture, in seed trays and seed beds should be sterilized before use. Simple methods of sterilization are to heat the moistened soil mixture at a temperature of $100^{\circ} \mathrm{C}$ for about 15 to $30 \mathrm{~min}$, cover the mixture to prevent contamination and allow to cool. An alternative is to spread the soil in a thin layer on a metal sheet and heat it over a fire for half an hour. Although various chemicals such as methyl bromide and formalin can be used for soil sterilization, many of these are dangerous to human beings.

\subsection{Seed Sowing}

Seed may be sown directly into the pots, or it may be sown first in seed beds or seed trays and the seedlings are later pricked out into the pots. 


\subsection{Pricking Out}

The best time for pricking out for most species is when the seedlings is usually $2-4 \mathrm{~cm}$ tall with one to two pairs of true leaves in addition to the cotyledons. Pricking out should be done under shade.

\subsection{Layering}

In air layering, the stem is girdled by removing a strip of bark 3-8 mm wide and the surface scraped to ensure the removal of all phloem. In soil layering the branches are bent down to the soil, pegged down and covered by a layer of soil.

\subsection{Root pruning}

Root pruning is done before root development is advanced by cutting the tap root and all lateral roots.

\subsection{Fertilizers}

The type of fertilizers used for various species are summarized below: -

\section{Nitrogen fertilizers:}

Sodium Nitrate $(16 \% \mathrm{~N})$ is good for broad-leaved species. Calcium Nitrate $(16 \% \mathrm{~N})$ is preferable for acid soils. Ammonium Nitrate $(35 \% \mathrm{~N})$ is suitable for broadleaves and conifers. Ammonium Sulphate $(200 \% \mathrm{~N})$, preferable for conifers.

\section{Phosphate fertilizers:}

Super phosphate is good for calcium deficient soils while double super phosphate used for all soils except for the calcium deficient.

\section{Potassium fertilizers:}

Potassium chloride and Potassium sulphate, good for all soils.

\subsection{Nursery Diseases and Pests}

\section{Fungal Diseases and their Control}

Damping off is caused by a wide range of fungi, including species of Pythium, Phytopthtora, Fusarium and Rhizoctonia. Damping-off can be considerably reduced and often eliminated by removal of shade from seedlings and avoiding the use of organic material in the potting mixture unless it is sterilized. A soil with a high $\mathrm{pH}$ value will tend to encourage damping-off.

\section{Plantation Techniques for Climate Resilient Seedlings}

Before planting a species on a given site, climatic and biotic/abiotic information are important to collect. Plantation plan containing details on location and area, species to be planted, site preparation, seedling transport, planting-hole digging, weeding, protection schedule of plantation activities, manpower, equipment and budgetary requirements must be prepared. Site is prepared to reduce competition to the planted trees. The optimum spacing in forest plantations depends on rate of growth of tree, its form, availability of nutrients and soil moisture, effects of grass and weed competition, danger of fire, and rotation to be adopted. The number of plants per hectare can be calculated by the following formula referred by Khanna, 1991 .

$N=\frac{A}{X * Y}$

Where, $\mathrm{N}=$ the number of plants per hectare

$\mathrm{A}=10,000$ sq. metres (one hectare)

$\mathrm{X}=$ spacing distance in the line (metres)

$\mathrm{Y}=$ spacing distance between lines (metres).

Normally polypot seedlings are planted in pit $(30 \times 30 \mathrm{~cm})$ by tearing off polythene bags.

\section{Plantation Techniques for Bamboo}

Several species of bamboo should be used as it allows synchronized flowering that prevent the bamboo clumps becoming weak or die during flowering (Janzen, 1976). The use of rhizome cuttings has been the traditional method in Nepal for hundreds of years. However, rhizome cuttings weigh 40 
$\mathrm{kg}$ on average (Stapleton, 1987), and so are impractical for planting-up large areas. Culm cuttings are much lighter, weighing about $0.5 \mathrm{~kg}$ (Storey, 1981; Stapleton C. , 1985). Culm cuttings are not always as successful as rhizome cuttings, but are still very useful, taking into consideration that only one plant can be obtained from a root, but several from a stem. Bamboo should have spacing of 3 to 5 feet apart to form a dense screen. However, to make a full-size bamboo grove with less emphasis on dense screening, planting at wider intervals is recommended (5-10 feet apart or even 20 feet in some cases). In case of bamboo plantation, the pit size of $45 \mathrm{~cm} \times 45 \mathrm{~cm} \times 45 \mathrm{~cm}$ (National Bamboo Mission, 2015) is recommended according to the government norms issued by the MoFE. Cutting should be planted in pit taking care of branch buds or young branch shoots.

\section{Plantation Techniques for Broom Grass}

In order to grow broom-grass the slips in the planting site must be clear of weeds and debris. It is usually planted at the beginning of monsoon season during the months of May to June as the soil has the best moisture for plant genesis. One month before planting pits of $30 \mathrm{~m}$ cubed should be dug up and left for weathering. On hilly land the pits should be placed about $1.5 \times 2 \mathrm{~m}$ apart along the contour lines or trace bunds, while on fertile land the best spacing is $2.5 \times 2.5 \mathrm{~m}$. Farm yard manure and $10 \%$ BHC fertilizer at 10 grams per pit are mixed into the pits before planting the seeds. Weeding is required 3-4 times in the first year and annually in the following years. Manure can be applied to the soil during the second weeding to provide the best yields in the first year. The pits need to be fenced off to protect the plants from grazing (Bisht \& Ahalawat, 1998).

\section{Plantation Techniques for Large Cardamom}

Suitable variety of large cardamom that have high production potential, resistance power and high adaptability in given altitude must be selected.

Table2. Variety of Cardamom in suitable altitudes

\begin{tabular}{|l|l|l|}
\hline SN & Varieties & Suitable altitudes \\
\hline 1 & Seremna & $1200 \mathrm{~m}$ up to $1800 \mathrm{~m}$ \\
\hline 2 & Bharlangey & $>1500 \mathrm{~m}$ up to $2200 \mathrm{~m}$ \\
\hline 3 & Chibeysai & $1300 \mathrm{~m}$ up to $1800 \mathrm{~m}$ \\
\hline 4 & Dzongu-Golsai & $<1000 \mathrm{~m}$ \\
\hline 5 & Ramsai & $1200 \mathrm{~m} \mathrm{up}$ to $1600 \mathrm{~m}$ \\
\hline 6 & Ramla & $1200 \mathrm{~m}$ up to $1600 \mathrm{~m}$ \\
\hline 7 & Sawney & $900 \mathrm{~m}$ up to $1500 \mathrm{~m}$ \\
\hline
\end{tabular}

Large cardamom grows well in loamy soil that is brownish yellow to dark brown in colour, at a soil depth of $15 \mathrm{~cm}$ to a few inches. Cardamom can be grown in sandy soil, sandy loam, silty loam or clay. It grows well on gentle to medium slopes, or even on flat lands with proper drainage that prevents water logging. Suitable planting time for large cardamom starts from the beginning of monsoon, i.e., middle of May-June (Baisakh-Jestha) when the soil has enough soil moisture. The field is ploughed, and small pits of $30 \times 30 \mathrm{~cm}$ are prepared on the contours at a space of around $1.5 \times 1.5 \mathrm{~m}$ from the pit. Saplings (suckers) are planted on the pits up to the collar region, avoiding deep planting and tightening the soil in pits by stepping over it. Mulching can be done around the plant base. Farmers are advised to keep the spacing in plantation small $(1 \mathrm{x} 1 \mathrm{~m})$ in the initial phase so that they can harvest the planting material in the second and third year (Sharma, Joshi, \& Gurung, 2017).

\section{Technical Support}

$\mathrm{EbA}$ is an eco-centric approach concerned with measures to conserve, restore and sustainably manage ecosystems and natural resources to generate valuable co-benefits such as conservation and restoration of forests, coastal vegetation or peat lands enhancing carbon sequestration (Duarte et al. 2013) and preventing of deforestation and land degradation that aids in limiting further greenhouse gas emission (Busch, et al., 2015). The major intervention of EbA South project for restoration of forest and degraded land included seedling production, distribution and plantation of climate resilient seedlings. 

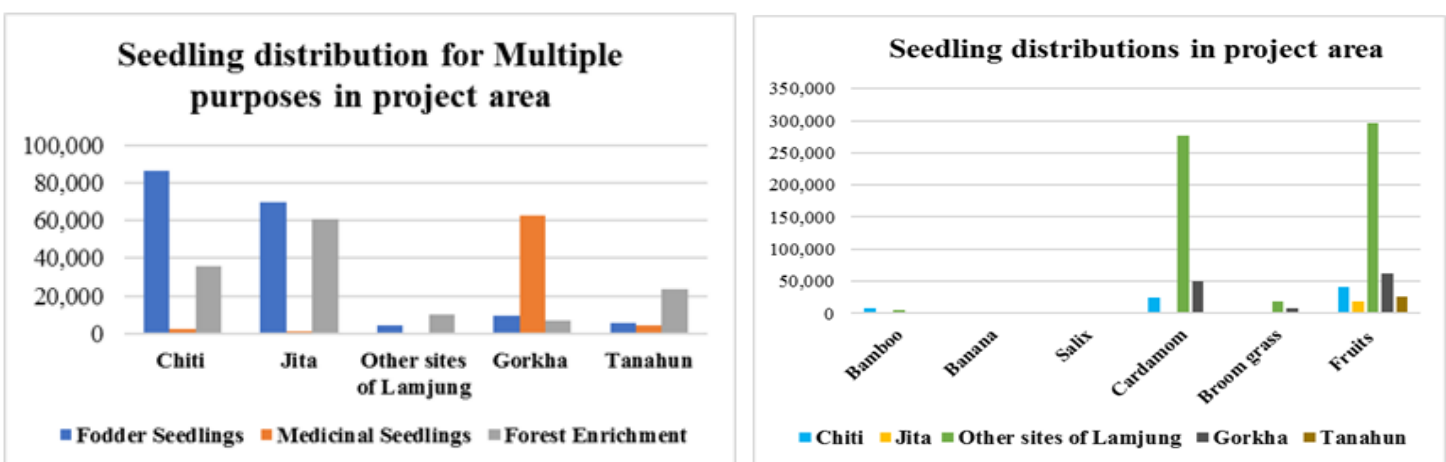

\section{Distribution and Plantation of Seedlings}

For the reforestation and enrichment more than 840,000 seedlings of different plants including fodders, fruits, climate resilient species, rhizomes and suckers, etc. were distributed in between 2014 to 2018. A total of 383,776 seedlings of climate resilient plants were distributed for forest enrichment, including 176,278 fodder, 70,374 medicinal and 137,124 forest enrichment seedlings. In order to protect the degraded riverbanks, a total number of 13,764 culms of bamboo, 2,500 suckers of banana, and 565 cuttings of Salix were distributed for plantation in Chiti of Lamjung and surrounding area. A total of 25,825 seedlings of broom-grass were planted in Jita of Lamjung and Bhandarthowk of Gorkha. The interventions also included plantation of fruit orchards and cardamom; accordingly, a total of 65,848 fruit seedlings and 351,380 cardamom seedlings for livelihood as agroforestry were distributed since 2015 to 2018 (Bogati \& Bhuju, 2019). The beneficiaries were positive and enthusiastic towards plantations as around 312 ha of land has been reforested and restored in Lamjung, Gorkha and Tanahun districts.

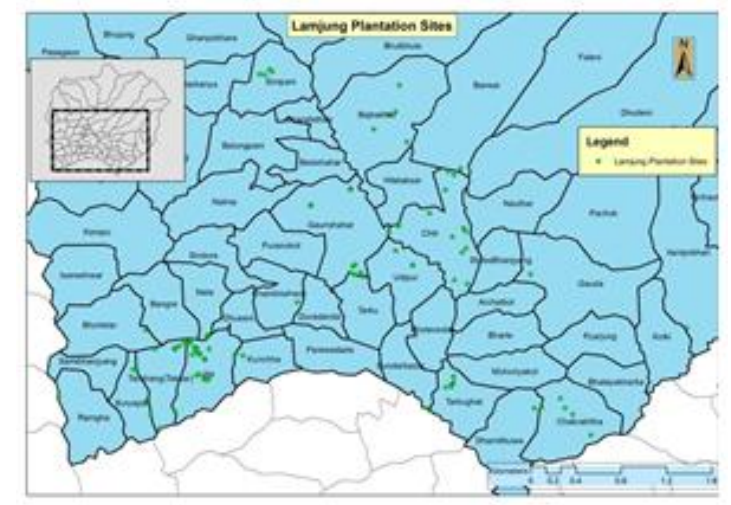

Figure3. Climate resilient seedlings plantation sites of Lamjung

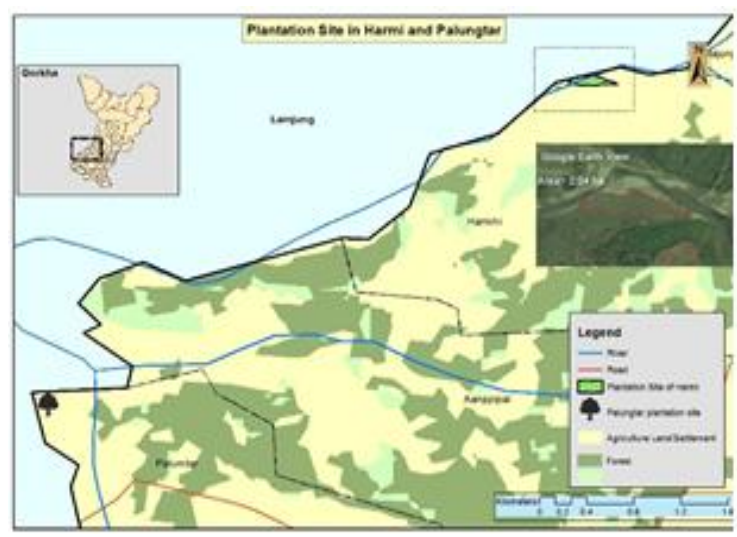

Figure4. Plantation sites of Gorkha

\section{Survivorship of Planted Seedlings}

Among the distributed seedlings in project area, survival of planted seedlings was higher in Chiti than Gorkha and Tanahun as dead seedlings in Chiti were replaced and replantation was done. An average survivorship of the planted seedlings was around 60\%. In Tahahun and Chiti, Lamjung, the 
survivorship was higher, with $69 \%$ and $62 \%$ respectively. Salix in landslide prone area could not grow as most of seedlings planted in riverbed was swept away by river while seedlings planted in sloppy land above the river bed were found surviving. Among the distributed fruits orchards, $50 \%$ of seedlings did not survive among some households in upper part of Jita because of dry climatic condition. Seedlings of Mango and Litchi were found well grown in Manakamana, Gorkha (Bogati \& Bhuju, 2019). Higher survival of seedlings was found in household plantation than community plantation. To ensure the survival of plantation, cow dung was added around the base of the plants to both act as fertilizer and protect from insects.

\section{Restoration of Forest, Degraded Land and Derivation of Multiple Benefit through Plantation}

EbA South project helped in restoration and enrichment of degraded and barren community forests, leasehold forests, private forests by protecting them to promote biodiversity, reduce climate change effects and use forest resources in future through community involvement. EbA South project help to increase resilience of climate vulnerable people to cope with disaster such as landslide and soil erosion. Plantation of fodder seedlings helped people to have easy access of fodder as well as cope with soil erosion and landslide. Broom Grass provided multiple benefit as fuel, broom, fodder, soil conservation and income source for rural communities to promote their livelihood. Plantation helped community to combat soil erosion, increase ground fertility, provide fodder and improve income source through selling of fruits, broom, parts of plants for medicine and Cardamom fruits.

Uplifted by plantation (Case study): Kopala Chepang and her family, from Beshishar Municipality, Ward No. 11, of Chiti, Lamjung is very happy and satisfied with EbA South project. Initially banana saplings were distributed for plantation in Chiti, Chepang Tar village in 2014. Kopala Chepang and her husband started planting them along the edge of riverbank. They also received grant for planting banana. Before banana plantation there used to be bushes and was the abandoned forest land where cattle graze. Due to the riverbank and sloppy dry land, erosion used to occur in rainy season. Now, 9 households have planted banana which was provided by EbA south project. They nurtured and protected banana from cattle grazing. Ultimately, soil erosion has also stopped due to banana plantation. Time and again, EbA South encouraged the Chepang community for plantation. Marginalized groups like us faced economic crisis as we are uneducated and have no links and ideas to get better opportunities. Overcoming this problem was made possible through this EbA South project" says Kopala Chepang.

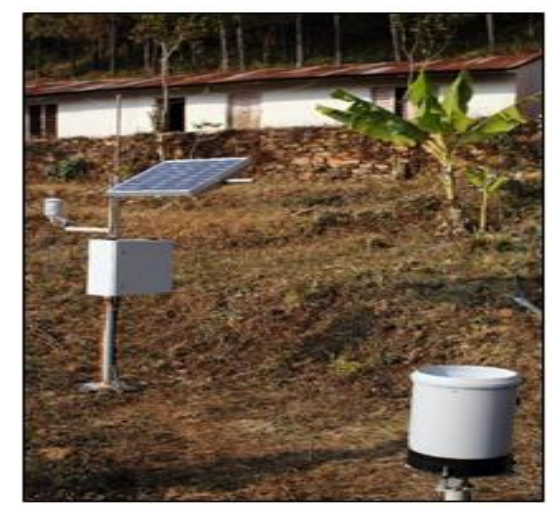

Figure5. Automatic weather station

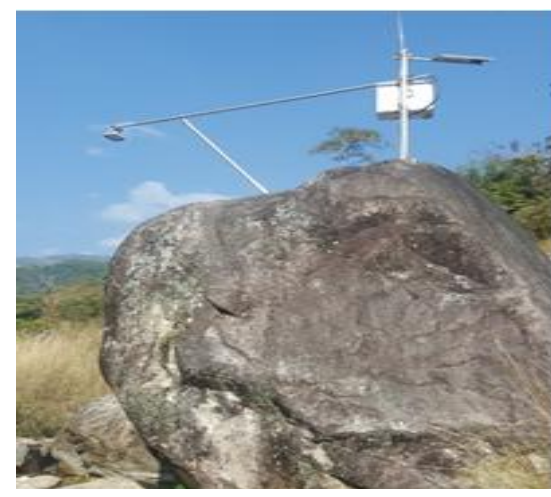

Figure6. Hydrological Station 


\section{Knowledge Management \\ Monitoring station}

One long-term monitoring station is established in Chiti for monitoring of short term and long-term effects of EbA interventions. An automatic weather station with air temperature, humidity sensor \& tipping bucket rain gauge has been installed within the premises of Jana Kalyan Secondary School Tilahar, Chiti that provides data on temperature, relative humidity \& precipitation at interval of an hour, which is stored and managed by Department of Hydrology \& Metrology (DHM). An automatic hydrological station with Radar Level sensor has been installed in Dwang khola that provide hourly water level information. 35 soil samples pits were fixed representing different land use, land system, altitude in Chiti and 32 soil sample pits fixed in Jita \& Takshar VDCs. A total of 3 runoff \& soil erosion monitoring plots sized 5X5 m were established in Chiti VDC within forest and agriculture land. 29 forest/vegetation monitoring plots are established in Chiti and 30 plots in Jita \& Takshar VDC. Long term monitoring sites established for integrated research works, assess the short and longterm effects of EbA South project and to provide an evidence base for future EbA up-scaling.

\section{Research grant}

Under long term research project, nine research grants have been provided for M.Sc. degree and 1 for $\mathrm{PhD}$ degree. Research grants was provided to develop and publish postgraduate thesis, research report, and peer reviewed research paper based on monitoring and research results. Research grant was provided in different thematic area i.e. climate change along with its impact on water resources and livelihood, regeneration status of forest under $\mathrm{EbA}$, soil characterization, production and sustainability of marketing of NTFPs.

\section{Issues Raised on Reforestation}

Various barriers and hindrances interrupted the implementing of the project activities. The barriers identified were limited interest from community members because of a shortage of local labor, limited awareness raising in communities and low demand for seedlings by community members, an underperformance of the nursery due to the limited technical capacity of the nursery manager, low seedling production in 2 sites of Lamjung and subsequent limitation in the distribution of seedlings, resulting in a shortage of seedlings for reforestation and enrichment activities. Out of total seedling distributed $77.49 \%$ were only planted in entire Lamjung district, rest were damaged during transportation and/or did not reach the plantation sites. Forest fire, cattle grazing and lack of watering to the seedlings during early plantation stage reduced the survivorship of the plants in the project area. Lack of local human resources in the village resulted lack of care of seedlings with no cleaning and weeding of undesired grasses resulted in low survival of seedlings. Some villagers destroyed the seedlings planted in bare land, before they grew up due to fear of wildlife due to perception that human-wildlife conflict might increase due to dense forest.

\section{Lesson Learnt from Eba Project}

\section{Nursery Establishment}

In the project area (Chiti and Jita), there was smaller number of seedling distribution (60\% every year) than seedling production in the community and farmers due to high mortality rate of seedlings production, inconsistent demand of seedlings resulting leftover seedlings in the nursery (EbA protocol). It was learnt that demand on number and species from the farmers and community, public announcement (Radio, newspaper) about seedlings distribution and awareness on benefits of restoration can enhance the proper use of seedlings produced in nursery. In chiti and Jita termination of the project would result to the closure of this nursery, due to lack of financial support but in Archalbot, Nursery will continue due to assistant from DFO Lamjung. This indicate that for the sustainability of project activities, there is a need of contribution from local level.

\section{Restoration species}

Table3. Benefits and lesson learnt from restoration species

\begin{tabular}{|c|c|c|c|}
\hline SN & Species & Benefits & Lessons learned \\
\hline 1 & Amala & $\begin{array}{c}\text { Economic benefits: Fruits, seed yield oil } \\
\text { Environmental benefits: Control soil } \\
\text { erosion/landslide, fruits and habitat for birds and } \\
\text { animals }\end{array}$ & $\begin{array}{c}\text { High demand by farmers to grow in } \\
\text { farmland; Survives in less moisture } \\
\text { soil condition }\end{array}$ \\
\hline
\end{tabular}




\begin{tabular}{|c|c|c|c|}
\hline 2 & Bakaino & $\begin{array}{c}\text { Economic benefits: Fodder; timber for } \\
\text { furniture; fuelwood; barks, flowers \& fruits used } \\
\text { in medicine } \\
\text { Environmental benefits: Control soil erosion, } \\
\text { landslide; habitat for birds }\end{array}$ & $\begin{array}{l}\text { Not a popular species among local } \\
\text { people from Jita \& Takshar; general } \\
\text { survival rate in plantations are not } \\
\text { good; Seedlings more than } 12 \\
\text { months age are not plantable }\end{array}$ \\
\hline 3 & Bel & $\begin{array}{l}\text { Economic benefits: Sacred plants of hindu; } \\
\text { fruits used for juice, toffee, pulp powder; used in } \\
\text { medicine } \\
\text { Environmental benefits: Tolerant in } \\
\text { waterlogging, wide range of temperature }\end{array}$ & $\begin{array}{l}\text { Few demands by farmers; Good } \\
\text { survival rate }\end{array}$ \\
\hline 4 & Chiuri & $\begin{array}{c}\text { Economic benefits: seeds for vegetable butter } \\
\text { and soap production } \\
\text { Environmental benefits: good habitat and } \\
\text { Nectar for birds, bees and bats; }\end{array}$ & $\begin{array}{l}\text { Indigenous people have high } \\
\text { demand of this species; plants can } \\
\text { have grown in hills and land with } \\
\text { shallow soil }\end{array}$ \\
\hline 5 & Ipil Ipil & $\begin{array}{l}\text { Economic benefits: Fodder, Fuelwood, timber } \\
\text { Environmental benefits: Nitrogen fixer }\end{array}$ & $\begin{array}{c}\text { Low demand for private land; } \\
\text { survival rate is average; careful } \\
\text { protection can increase survival rate }\end{array}$ \\
\hline 6 & $\begin{array}{c}\text { Rai } \\
\text { Khanyu }\end{array}$ & $\begin{array}{l}\text { Economic benefits: Fodder, Fuelwood } \\
\text { Environmental benefits: control soil erosion } \\
\text { and provide fruits for birds and animals }\end{array}$ & $\begin{array}{l}\text { High demand by farmers to grow in } \\
\text { their farmland; survival rate is higher } \\
\text { in private land due to good care of } \\
\text { watering, weeding and using } \\
\text { manures }\end{array}$ \\
\hline 7 & Simal & $\begin{array}{c}\text { Economic benefits: Timber, fuelwood and } \\
\text { fodder, Young flowers can be eaten as a } \\
\text { vegetable, Roots and gum are used in medicine } \\
\text { Environmental benefits: Good habitat for birds } \\
\text { especially birds of prey }\end{array}$ & $\begin{array}{c}\text { Survival rate is average; Natural } \\
\text { growth has higher survival rate than } \\
\text { plantation }\end{array}$ \\
\hline 8 & Tanki & $\begin{array}{c}\text { Economic benefits: Fodder, fuelwood, buds \& } \\
\text { flowers used as vegetables } \\
\text { Environmental benefits: control erosion, } \\
\text { habitat for birds }\end{array}$ & $\begin{array}{l}\text { Farmers have high demand } \\
\text { compared to community forests; } \\
\text { Survival rate is high }\end{array}$ \\
\hline 9 & Tejpat & $\begin{array}{c}\text { Economic benefits: Barks and leaves used for } \\
\text { flavoring, spices and in medicines } \\
\text { Environmental benefits: Control erosion \& } \\
\text { landslide; forest restoration }\end{array}$ & $\begin{array}{l}\text { High demand by farmers; farmers } \\
\text { prefer due to its economic value to } \\
\text { income generation through sell of } \\
\text { leaves and barks }\end{array}$ \\
\hline 10 & Khair & $\begin{array}{l}\text { Economic benefits: Fuelwood, fodder, used in } \\
\text { medicine, tanning \& dyeing } \\
\text { Environmental benefits: control soil erosion in } \\
\text { river banks, forest restoration }\end{array}$ & $\begin{array}{l}\text { Preferred by community forests to be } \\
\text { planted in river banks, survival rate } \\
\text { is high, protection from grazing is } \\
\text { the most }\end{array}$ \\
\hline 11 & Koiralo & $\begin{array}{c}\text { Economic benefits: Flower buds used as } \\
\text { vegetable \& pickle, Fodder, fuelwood, mulching } \\
\& \text { agricultural tools } \\
\text { Environmental benefits: Control soil erosion, } \\
\text { landslide, birds nesting and wildlife habitat }\end{array}$ & $\begin{array}{l}\text { High demand by farmers for } \\
\text { farmland; planted in terraces and } \\
\text { private forests, high survival rate }\end{array}$ \\
\hline 12 & Lapsi & $\begin{array}{l}\text { Economic benefits: Fruits used for pickle, } \\
\text { fodder, fuelwood, timber, mulching } \\
\text { Environmental benefits: control soil erosion in } \\
\text { terraces }\end{array}$ & $\begin{array}{c}\text { Farmers demand due to its economic } \\
\text { value; Survival rate is low as it needs } \\
\text { care after plantation }\end{array}$ \\
\hline 13 & Gulmohar & $\begin{array}{c}\text { Economic benefits: Ornamental tree, fuelwood, } \\
\text { fodder } \\
\text { Environmental benefits: flower and fruits } \\
\text { consumed by birds and monkeys in urban areas }\end{array}$ & $\begin{array}{l}\text { Planted in urban forestry, road side } \\
\text { plantation and for ornamental } \\
\text { purposes }\end{array}$ \\
\hline 14 & Nimaro & $\begin{array}{c}\text { Economic benefits: Fodder, fruit used for } \\
\text { making jam } \\
\text { Environmental benefits: erosion control, } \\
\text { habitat for birds }\end{array}$ & $\begin{array}{l}\text { Preferred by farmers in their } \\
\text { farmland }\end{array}$ \\
\hline 15 & Amba & $\begin{array}{l}\text { Economic benefits: Fruit, timber, fuelwood } \\
\text { Environmental benefits: soil erosion control }\end{array}$ & $\begin{array}{l}\text { Natural growth has higher survival } \\
\text { rate; Care and protection from } \\
\text { grazing can enhance survival rate; it } \\
\text { is light demanding plants and can be } \\
\text { grown in agroforestry system }\end{array}$ \\
\hline
\end{tabular}




\begin{tabular}{|c|c|c|c|}
\hline 16 & $\begin{array}{l}\text { Khote } \\
\text { Salla }\end{array}$ & $\begin{array}{c}\text { Economic benefits: Timber, Resin } \\
\text { Environmental benefits: Forest restoration }\end{array}$ & $\begin{array}{l}\text { Survive and grow well on shallow } \\
\text { soil, low water table condition; }\end{array}$ \\
\hline 17 & Ritha & $\begin{array}{l}\text { Economic benefits: Fruits used for soap } \\
\text { making; medicinal use for treatment of epilepsy; } \\
\text { Fodder, timber } \\
\text { Environmental benefits: erosion control }\end{array}$ & $\begin{array}{l}\text { It is more suitable for individual } \\
\text { farmers to plant near their houses } \\
\text { which needs good care }\end{array}$ \\
\hline 18 & Sissoo & $\begin{array}{c}\text { Economic benefits: Timber, fodder, fuelwood } \\
\text { Environmental benefits: Erosion control, } \\
\text { control land cutting }\end{array}$ & $\begin{array}{l}\text { Grows well in natural habitat eg., } \\
\text { Gorkha Tunebotebagar; }\end{array}$ \\
\hline 19 & Babul & $\begin{array}{c}\text { Economic benefits: Fodder, fuelwood } \\
\text { Environmental benefits: Habitat for birds }\end{array}$ & Survival rate is low \\
\hline 20 & Harro & $\begin{array}{c}\text { Economic benefits: Furniture, fodder, fruits } \\
\text { used in tanning and medicine } \\
\text { Environmental benefits: Birds habitat, animals } \\
\text { browse, erosion control }\end{array}$ & $\begin{array}{c}\text { Farmers prefer in private farmland, } \\
\text { Survival rate is low, Regular } \\
\text { watering, weeding can enhance } \\
\text { survival rate }\end{array}$ \\
\hline 21 & Masala & $\begin{array}{l}\text { Economic benefits: Timber, Fuelwood, poles, } \\
\text { medicinal use } \\
\text { Environmental benefits: Grows in waterlogged } \\
\text { area fast growing species }\end{array}$ & $\begin{array}{l}\text { Grows fast in low land, survival rate } \\
\text { is high }\end{array}$ \\
\hline 22 & Badahar & $\begin{array}{c}\text { Economic benefits: Fodder, Fuelwood, fruit, } \\
\text { timber } \\
\text { Environmental benefits: erosion control }\end{array}$ & Farmers planted near their house \\
\hline 23 & $\begin{array}{l}\text { Cassia } \\
\text { seamia }\end{array}$ & $\begin{array}{c}\text { Economic benefits: Fuelwood, fodder, stem for } \\
\text { decorative items } \\
\text { Environmental benefits: erosion control }\end{array}$ & $\begin{array}{l}\text { Good survival rate when mixed with } \\
\text { other broadleaved plants }\end{array}$ \\
\hline 24 & $\begin{array}{l}\text { Gobre } \\
\text { Salla }\end{array}$ & $\begin{array}{c}\text { Economic benefits: Timber, Resin, Fuelwood } \\
\text { Environmental benefits: erosion control }\end{array}$ & High survival rate \\
\hline 25 & Teak & $\begin{array}{l}\text { Economic benefits: Timber } \\
\text { Environmental benefits: Shade, reforestation }\end{array}$ & \\
\hline 26 & Okhar & $\begin{array}{c}\text { Economic benefits: Fruits, Bark \& leaves have } \\
\text { medicinal uses, timber } \\
\text { Environmental benefits: Shade, ornamental } \\
\text { plant }\end{array}$ & Planted in private land \\
\hline 27 & Champ & $\begin{array}{c}\text { Economic benefits: Fodder, Timber, Flowers } \\
\text { for perfume and medicinal value } \\
\text { Environmental benefits: Erosion control, } \\
\text { restoration }\end{array}$ & $\begin{array}{l}\text { Planted both in community \& private } \\
\text { forests }\end{array}$ \\
\hline
\end{tabular}

\section{CONCLUSION}

Climate change impacts including crop losses from droughts, flood and topsoil losses from increased soil erosion and landslide pose a serious risk to vulnerable community increasing exposure and sensitivity to climate induced stress and shocks. EbA South Project assisted the vulnerable community in Africa and Asia-Pacific to adapt to the impacts of climate change by improving their capacity to plan, implement, finance, research and legislate in support of Ecosystem based adaptation. This project strengthens capacity building at local, national and regional levels to plan and implement climate change adaptation technologies. EbA South project increased social and ecosystem resilience to climate change through plantation of climate resilient seedlings for reforestation and agro-forestry, bamboo suckers and Salix seedlings on degraded riverbanks and seedlings in fruits orchards at project sites. Vulnerable communities of Tanahun, Lamjung and Gorkha got benefited through capacity building in Nursery establishment, seedling production, plantation techniques, for climate resilient seedlings. Restoration of degraded forest and land increased resilience of climate vulnerable people to cope with disaster such as landslide and soil erosion. Plantation helped community to combat soil erosion, increase ground fertility, provide fodder and improve income source through selling of fruits, broom, parts of plants for medicine. The beneficiaries were positive and enthusiastic towards EbA South project activities.

\section{REFERENCES}

[1] Ayers , J. (2011). Resolving the Adaptation Paradox: Exploringthe Potential for Deliberative Adaptation Policy-Makingin Bangladesh. Global Environmental Politics, 62-88.

[2] Bisht, N. S., \& Ahalawat, S. P. (1998). Broom Grass. 6, 1-10. 
[3] Bogati, R., \& Bhuju, D. (2019). Ecosystem Based Adaptation:Monitoring and Implemnentation Protocol of EbA Interventions. Kathamandu, Nepal: Resources Himalaya Foundation .

[4] Busch, J., Ferretti-Gallon, K., Engelmann, J., Wright, M., Austin, K. G., Stolle, F., \& Baccini, A. (2015). Reductions in emissions from deforestation from Indonesia's moratorium on new oil palm, timber, and logging concessions. Proceedings of the National Academy of Sciences, 112 (5), 1328-1333.

[5] Duarte, C. M., Losada, I. J., Hendriks, I. E., Mazarrasa, I., \& Marba, N. (2013). The role of coastal plant communities for climate change mitigation and adaptation. Nature Climate Change, 3 (11), 961.

[6] INDC. (2016). Intended Nationally Determined Contributions. Kathmandu: Government of Nepal Ministry of Population and Environment.

[7] IPCC . (2007). Climate Change 2007: Impacts, Adaptation and Vulnerability. Contribution of Working Group II to the Fourth Assessment. Cambridge, UK: Cambridge University Press.

[8] IPCC. (2007). AR4 Climate Change 2007: Synthesis Report.

[9] IUCN. (2017). Ecosystem Based Adaptation issues brief. Retrieved from iucn.org/eba: https://www.iucn.org/sites/dev/files/import/downloads/ecosystem-based_adaptation_issues_brief_final.pdf

[10] Janzen, D. H. (1976). Why Do Bamboos Wait So Long To Flower. Annual Review of Ecology \& Systematics (7), pp. 347-391.

[11] Khanna, L.S. ( 1991).Principles and Practice of Silviculture. Khanna Bandhu $2^{\text {nd }}$ Edition, New Delhi.

[12] Munjuga, M., Gachuir, A. N., Ofori, D. A., Mpanda, M. M., Muriuki, J. K., Jamnadass , R. H., \& Mowo, J. G. (2013). Nursery management, treepropagation and marketing: A training manual for smallholder farmers and nursery operators. . Nairobi, Kenya: World Agroforestry Centre .

[13] NAPA. (2010). National Adapatation programme of Action to Climate Change. Kathmandu, Nepal: Ministry of Environment, Government of Nepal.

[14] National Bamboo Mission. (2015). Manual for establishment and management of Bamboo plantation.

[15] Regmi, B. R., \& Bhandari, D. (2013). Climate Change Adaptation in Nepal: Exploring. Forests and Livelihood.

[16] Sharma, G., Joshi, S. R., \& Gurung, M. B. (2017). Climate-resilient practices for sustainability oflarge cardamom production systems in Nepal - Resource Book for Farmers. ICIMOD Manual 2017. Kathmandu: ICIMOD.

[17] Smit, B., Burton, I., Klein , R. T., \& Street , R. (1999). The Science of Adaptation: A Framework for Assessment Mitigation and Adaptation Strategies for Global Chang. 199-213.

[18] Stapleton, C. (1985). Studies on Vegetative Propagation of Bambusa and Dendrocalamus Species by Culm Cuttings. In Recent Research on Bamboos (pp. 146-153).

[19] Stapleton, C. A. (1987). Bamboos, Gramineae. In J. K. Jackson, Manual of Afforestation in Nepal (pp. 199-214).

[20] Storey, P. J. (1981). Rural Development Conference. Lamachaur.

[21] UNFCCC. (2008). Publications. Retrieved 07 10, 2019, from UNFCCC: https://unfccc.int/resource/ docs/2008/smsn/igo/029.pdfbnm

[22] WFP. (2009). WFP Nepal - Food For Thought Series Issue 2, December 2009: The Future of Food Creating sustainable communities through climate adaptation. Retrieved 07 10, 2019, from Reliefweb: https://reliefweb.int/report/nepal/wfp-nepal-food-thought-series-issue-2-december-2009-future-foodcreating-sustainable

[23] WWF. (2019). Climate Change Adaptation. Retrieved 7 10, 2019, from WWF: http://www.wwfnepal.org/ hariyobanprogram/what_we_do/climate_change_adaptation

Citation: Tej Kumar Shrestha, et.al," Community-Based Watershed Restoration in Nepal: Learning from EBA South Project", International Journal of Forestry and Horticulture (IJFH), vol. 5, no. 4, pp. 22-35, 2019. Available: DOI: http://dx.doi.org/ 10.20431/2454-9428.0504003

Copyright: (C) 2019 Authors. This is an open-access article distributed under the terms of the Creative Commons Attribution License, which permits unrestricted use, distribution, and reproduction in any medium, provided the original author and source are credited. 